\title{
Alternative fuels for vehicles
}

\author{
Taha Younis Sabti \\ Department of Mechanical Engineering - College Of Engineering - Kufa University
}

\section{Abstract:}

The purpose of this paper is based on a review of technical literature on the topic of alternative fuel for vehicles (AFVs) which describes the advantages and disadvantages compared to conventional vehicles running on conventional fuels (diesel and gasoline).

In addition, the study included the emissions of a fuel cell vehicle (FCV) and internal combustion engine vehicle (ICEV).Global warming; climate change, greenhouse gas (GHG) emissions, and the quality of the air have all been a major concern in the next decades. It is important to identify the major contributors to greenhouse gas emissions in order to develop effective methods and strategies for their reduction. The transportation sector is responsible for a great percentage of the greenhouse gas emissions as well as the energy consumption in the world [18].Ultimately; we will need to replace gasoline with a zero - carbon fuel. All AFVs that have so far been promoted with limited success (electric vehicles, natural gas vehicles, methanol vehicles, and ethanol vehicles) have been each suffered from several of these barriers. Any one from these barriers can be a showstopper from an AFV, even where other clear benefits are delivered.Increasingly alternative economies are being suggested, whereby the growing energy demand of the future is met with greater efficiency and with more renewable energy sources such as ethanol, methanol, biodiesel, hydrogen, wind, solar and biomass.

Hydrogen is being promoted as an alternative energy carrier for sustainable future. Many scientists argue that its use as a transportation fuel offers a number of attractive advantages over existing energy sources. It is a high quality carbon-free energy carrier, which can achieve improved efficiencies at the point of use with reduced or zero GHG emissions over the entire "well-to-wheel" (WTW) life cycle. These benefits are even future underpinned by the fact that hydrogen can be manufactured from primary energy sources, such as natural gas, coal, biodiesel, ethanol, methanol, wind, solar and biomass, contributing towards greater energy security and flexibility.

Key words: alternative fuels, renewable energy, hydrogen. 


\section{Introduction:}

Alternative fuels are, by definition, the substantially non-petroleum and yield energy security and environmental benefits. Alternative fuel vehicles (AFVs) - cars and trucks that operate on fuels other than gasoline and diesel. The development of alternative fuels boasts several secondary benefits. Alternative fuel usage could have a tremendous impact on reducing pollution since many types of alternatives boast significantly lower emissions. The transportation sector is responsible for a great percentage of the greenhouse gas emissions as well as the energy consumption in the world. The need for alternative fuels, other than petroleum, and the need to reduce energy consumption and greenhouse gases emissions are the main reasons behind this report, but the use of alternative fuels and the new stricter regulations on existing fuels are helping some countries to achieve a more energy efficient and environmentally friendly future.[2 ]

In addition, the peak in global conventional oil production between now and 2023 and the peak production date for natural gas and coal could occur by 2050 [4]. As shown from the Hubert Curve, (figure 1). [19]

The development of alternative fuel sources becomes increasingly pressing as a result. For these reasons, there has been tremendous interest and substantial public and private research into alternative-fuel for vehicles. Alternative fuel vehicles and their fuels face two central problems. First, they typically suffer from several marketplace disadvantages compared to conventional vehicles running on conventional fuels. Second, they typically do not provide costeffective solution to major energy and environmental problems [5].

The introduction of any new transportation fuel requires a significant capital investment and long-term commitment while facing high risks of poor short-term returns. It requires a simultaneous delivery of the new fuel at the refueling stations and introduction of new vehicles on the road, since neither is of any use without the other. Also, Increasingly alternative economies are being suggested, whereby the growing energy demand of the future is met with greater efficiency and with more renewable energy sources such as hydrogen, ethanol, methanol, wind, solar and biomass, especially in regards to the automotive industry.

\section{Hydrogen $(\mathrm{H} 2)$ as an alternative fuel}

In recent years, the interest in the use of hydrogen, as an alternative fuel for spark-ignition engines, has grown according to energy crises and environmental pollution. Hydrogen seems to be an ideal non-polluting fuel for vehicles: it burns cleanly, leaving just plain water $(\mathrm{H} 2 \mathrm{O})$ as a result of oxidation process. Hydrogen is by far the most abundant element in the universe and it is attractive as a fuel because it has highest energy density per unit of weight of any fuel $[2,8,14]$, as shown in Table 2.

Back in the 1970, Larry Williams, listed the following main hydrogen advantages [3]: $\square$ Lowest cost per unit energy, lowest weight per unit energy, simple supply logistics, normal refuels time required and no insurmountable safety problems.

In the long term, energy security - Global issue will achieve only by finding a substitute for gasoline. Hydrogen, particularly when used in fuel cells for transportation, offers an alternative that can reduce or even eliminate our dependence on foreign oil and improve energy security. Hydrogen can be produced from many domestic resources, including fossil fuels, such as natural gas and coal; renewable energy resources, such as solar energy, wind, and biomass; and nuclear energy. Developing clean, efficient, and costeffective hydrogen production, however, is a significant challenge. Hydrogen is not a fuel that exists in nature in a readily usable form, such as natural gas or coal. It more closely resembles electricity - an energy carrier that must be generated from another fuel source.[20]

Hydrogen is currently extracted by a variety 
of methods. The most common method is to use steam to extract hydrogen from natural gas, coal, or methanol. Electrolysis is also used - running a current through water to separate the hydrogen from its paired oxygen atoms. Finally, the photosynthetic processes in algae and plants, and even sunlight itself, have been adapted to provide raw hydrogen.

Unfortunately, none of these processes are especially efficient, and require significant energy inputs to complete. The infrastructure required to implement these methods at the level necessary to provide hydrogen amongst the general public (also known as the 'Hydrogen Economy') is also inadequate. Considerable state investment has, however, been made towards that end.

Unfortunately, due to its many shortcomings, the viability of hydrogen as a truly efficient source of energy is still undecided. Private automotive manufacturers have show cased a variety of hydrogen-powered vehicles at trade shows across the all nations.

Recent hydrogen-powered automobiles have been introduced such as the Toyota Prius, and a variety of Ford pickup trucks. Unfortunately, the technological hurdles presented by the unavailability of hydrogen fuel stations, the inflated price of hydrogen, and meager mileage (approximately 80-100 miles per tank), have discouraged their acceptance into the general marketplace.[3]

\section{Advancements in the Automotive}

\section{Industry:}

Hydrogen also can be used to fuel internal combustion engines and fuel cells, both of which can power low- or zero-emissions vehicles.

Vehicles with fuel cells that use hydrogen that's either produced on-board by converting liquid fuels (gasoline, ethanol, or methanol) to hydrogen, or by using direct hydrogen that has been generated off-board and stored on the vehicle in compressed or liquid form.

The US government [12] (more specially California), Canada and other countries have tried to promote AFVs for long time. Hydrogen initiative calls for a decision on the commercial viability of hydrogen-powered transportation in 2017. The result is Freedom CAR (Cooperative Automotive Research), currently the largest public-private partnership ever formed in the interest of hydrogen research. The project has involved the efforts of private automotive industry giants such as Ford Motor Company, DaimlerChrysler, and General Motors to develop hydrogen-powered transportation [3].Major energy providers have also been involved in the project in order to ensure that the development of hydrogen transportation will occur in conjunction with the infrastructure required to maintain it. The system, while promising on the surface, does not promise that hydrogen transportation will become a reality for at least the next ten to twenty years. Indeed, there have been no guarantees to the overall success of the initiative to date.

The U.S. Department of Energy (DOE) tested four internal combustion vehicles using hydrogen: a Dodge Ram van and a Ford F-150 with engines designed for compressed natural gas, a Ford F150 with a gasoline engine that was modified to run on a hydrogen/natural gas blend, and a Mercedes van with a gasoline engine modified to run on pure hydrogen. The tests showed the hydrogen lowered emissions and increased fuel economy (as compared to the engine on natural gas or gasoline alone)[3]. Ford Motor Company has developed an internal combustion engine optimized to burn hydrogen instead of gasoline. The engine can reach an overall efficiency of about 38 percent, about 25 percent more fuelefficient than a typical gasoline engine with nearly zero emissions.

For example, the State of California is committed to achieving a clean energy and transportation future based on the rapid commercialization of hydrogen and fuel cell technologies so that by 2010 every Californian will have access to hydrogen fuel, with a significant and increasing percentage produced from clean, renewable sources. [5]

The hydrogen technologies mentioned above 
however differ fundamentally in the following points:

1- Combustion engines running on hydrogen have the advantage of using a well-known and established technology. Manufacturers, service teams and customers alike will be able to rely on the experience that has been accumulated over the past decades.

2- Fuel cell technology.

\section{Alternative fuels compared with} vehicles fueled with conventional diesel and gasoline:

- Ethanol-fueled vehicles produce lower carbon monoxide and carbon dioxide emissions and the same or lower levels of hydrocarbon and non-methane hydrocarbon emissions. Oxides of nitrogen $\left(\mathrm{NO}_{\mathrm{x}}\right)$ emissions are about the same for ethanol and gasoline vehicles. (E85), some vehicles are specially manufactured to operate on an ethanol blend that contains up to 85 percent ethanol and at least 15 percent gasoline. The 15 percent gasoline is needed to assist in engine starting because pure ethanol is difficult to ignite in cold weather. E85 has fewer highly volatile components than gasoline and so has fewer evaporative emissions.

- The emissions from using biodiesel are much lower than diesel fuel. Biodiesel has no aromatic content and only trace amounts of sulfur. In vehicle tests, it has lower emissions of carbon monoxide, soot, and polycyclic aromatic hydrocarbons than conventional diesel. NOx emissions can be higher, but with adjustments in the injection engine timing, it is possible to reduce the NOx emissions. In addition, particulate emissions are essentially eliminated.

- A natural gas vehicles (NGVs) can produce significantly lower amounts of harmful emissions such as nitrogen oxides, particulate matter, and toxic and carcinogenic pollutants. NGVs can also reduce emissions of carbon dioxide, the primary greenhouse gas. For details, see the following publications from the U.S. Environmental Protection Agency:

- The cost of a gasoline-gallon equivalent of compressed natural gas (CNG) can be favorable compared to that of gasoline, but varies depending on local natural gas prices.

- Natural gas is mostly domestically produced. In 2004, a net import of natural gas was approximately $15 \%$ of the total used, with almost all the imports coming from Canada.

- Some natural gas vehicle owners report service lives 2 to 3 years longer than gasoline or diesel vehicles and extended time between required maintenance

- Propane and natural gas offer lower emissions of carbon monoxide, toxic hydrocarbons and ozone precursors. On the life-cycle basis, they also produce less greenhouse gas emissions than gasoline.

- Based on environmental considerations alone, propane is as good as, if not better than compressed natural gas (CNG).

- Hydrogen contains no carbon. An accidental release of hydrogen won't harm the environment, and there is no possibility of carbon monoxide poisoning.

- when mixed with air, hydrogen has a wide flammability range, but also a high rate of diffusion and dispersion. In the event of a leak, hydrogen actually poses less of a fire risk than gasoline or natural gas because it's quickly diffused and made harmless.

- If a flammable concentration does occur, hydrogen tends to burn in a flame rather than explode. That flame has a low radiant energy and do not heat areas close by. This reduces the risk of burns.

\section{Results and Discussion:}

The work carried out in laboratory of Internal Combustion Engines (I.C.E) / Waterloo University/ Canada, Ontario, 2007

Hydrogen as an energy carrier has garnered the most attention as a vehicle fuel for hydrogen 
fuel cell or combustion engine vehicles.

The study shows that the FCV vehicle will have lower emissions than the Internal Combustion Engines for Vehicle (ICEV) as summarized in Table 3 and Table 4 for the present and future vehicle, respectively. In order to compare the ICEV and FCV, the tables show the energy and emissions percentage difference taking the ICEV as the base.

The total energy consumption of the future ICEV is $25 \%$ less than the total energy consumption of the present ICEV. This is mostly to the change in gasoline production and to reducing the overall weight of the vehicle. The total carbon dioxide emissions of the future ICEV are $21 \%$ less than the present ICEV. The total energy consumption of the future FCV is $3.5 \%$ higher than that of the present FCV, due to the increased aluminum content for lighter vehicles. The total carbon dioxide emissions of future FCV are $12.1 \%$ higher than that of present FCV.

The emissions are lower for the FCV since the electro-oxidation process of hydrogen is not associated with any carbon dioxide emissions, while on the other hand the burning of conventional gasoline is. As it can be seen, the contribution of the fuel life cycle is much more for gasoline than it is for hydrogen.

As expected, it can be seen that extracting hydrogen via electrolysis from coal generates the highest emission and consumes the most energy in comparison with the other methods. Under the present conditions, extracting hydrogen via electricity from coal results in a total energy consumption by the FCV of $19 \%$ higher than ICEV and total emission of $50 \%$ more carbon dioxide. Similarly, under the future conditions, the FCV run on hydrogen extracted from electricity via coal will consume $62 \%$ more energy and emit $98 \%$ more carbon dioxide than ICEV. Therefore, if hydrogen is to become the primary fuel on the road, the use of coal to obtain hydrogen should be minimized. The use of nuclear power and natural gas to extract hydrogen has similar energy consumption but using nuclear power to extract hydrogen leads to consumption by FCV with hydrogen extracted via the nuclear power method is almost half of that of ICEV and the total carbon dioxide emissions are almost $87 \%$ lower for FCV than ICEV. For an FCV with hydrogen extracted via the NG method, the total energy consumption and total emissions are half of that of ICEV. Similarly, under the future conditions, the energy consumption by a FCV running on hydrogen extracted via the nuclear power method is $27 \%$ lower than that of an ICEV and the carbon dioxide emissions are lower by $77 \%$. For an FCV running on hydrogen extracted via the NG method, the total energy consumption is $27 \%$ less than that of ICEV and the total emissions are $37 \%$ lower than that of ICEV.

The total efficiency of ICEV and FCV consists of the will-to-tank efficiency and the tank-to-wheel efficiency. The well-to-tank efficiency of an ICEV is $80 \%$. The well-to-tank efficiency of a FCV depends largely on the method of obtaining hydrogen. Fig.2 shows the well-to-tank efficiency of methods considered in this study.

The tank-to-wheel efficiencies are 17.1 and $36 \%$ for an ICEV and a FCV, respectively [9]. The total efficiency is shown in Fig.3. This figure shows that extracting hydrogen via $\mathrm{NG}$ is the most efficient. Overall, the FCV is more efficient than the ICEV. The well-to-wheel efficiencies are 21.7 and $13.8 \%$ for a FCV and an ICEV, respectively.

The team work of Waterloo University, Department of Mechanical Engineering examined alternative fuels in laboratory of Internal Combustion Engines (I.C.E) / Waterloo University/ Canada, Ontario, 2007 and the experimentation has continued after my participation was completed.

Some alternatives are compared on this basis in Table 5 and Table 6 .Fuel must be easy to transfer to Vehicles and be safe and nontoxic in handling and use.

When comparing the two of vehicles (ICEV and FCV), it is very important to study the price difference. As mentioned before the weight of the vehicles will approximately be the same; the 
weight of fuel cell stack will approximately be similar to that of the internal combustion engine.

\section{Conclusions:}

There exist several fundamental problems when considering the viability of any alternative fuel for vehicle:

1. Firstly, the question of availability must be addressed: Is the fuel abundant enough to satisfy potential demand for an extended period of time (short or long term)?

- Until 2010: Entry phase into short - term alternative fuels and acceleration of renewable energy sources (RES) growth backed by energy police through target setting and support policies.

- 2010 - 2020: Stabilization of RES growth and gradual withdrawal of policy support, consolidation of the contribution of $\mathrm{CNG}$ and biofuels.

- 2020 - 2035: Full consolidation of new RES technologies in all end sectors, first of application of hydrogen in distinctive niches while maintaining the established alternative fuels.

- 2035 - 2050: Growing dominance of RES in all ends - use sectors and start of significant use of hydrogen.

- Beyond 2050: Gradual substitution of fossil energy by RES and large - scale establishment of hydrogen from RES in order to realize a hydrogen system by the end of the 21st century. [10]

2. Second, the issue of efficiency also comes to play: can the fuel be extracted using significantly less energy than the fuel actually provides?

3. Third, the issue of adaptability also comes into play: can the fuel be stored and utilized properly using currently existing means?

Finally, the question of transportability must be addressed: can the new fuel be easily transported from areas in which it is abundant to areas in which it is scarce?

The inability of alternative fuels to adequately answer each of the above questions has led to a great deal of frustration to researchers attempting to overcome such hurdles. To date, the hydrogen is most challenging of alternative fuels for vehicles proposed in most countries. Researchers speculate that it may be decades before its associated problems of inefficiency can be solved.

Alternative fuels such as Hydrogen may offer certain a number of attractive advantages over existing energy sources; especially in the transportation sector. Its clean-burning qualities, it's potential for domestic production and the fuel cell vehicle's potential for high efficiency (two to three times more efficient than gasoline vehicles).

Governments at all levels should continue their support for the use of gaseous alternative fuels as Hydrogen, since it is still the best options to provide energy security and environmental benefits compared to gasoline.

Finally, Hydrogen has many inherent advantages as an energy commodity. Its ability to compete will probably improve over time. Nevertheless, hydrogen fuel has serious limitations as well, such as in the areas of production, storage, safety, and efficiency. These will impose ongoing constraints on its use in the future. 


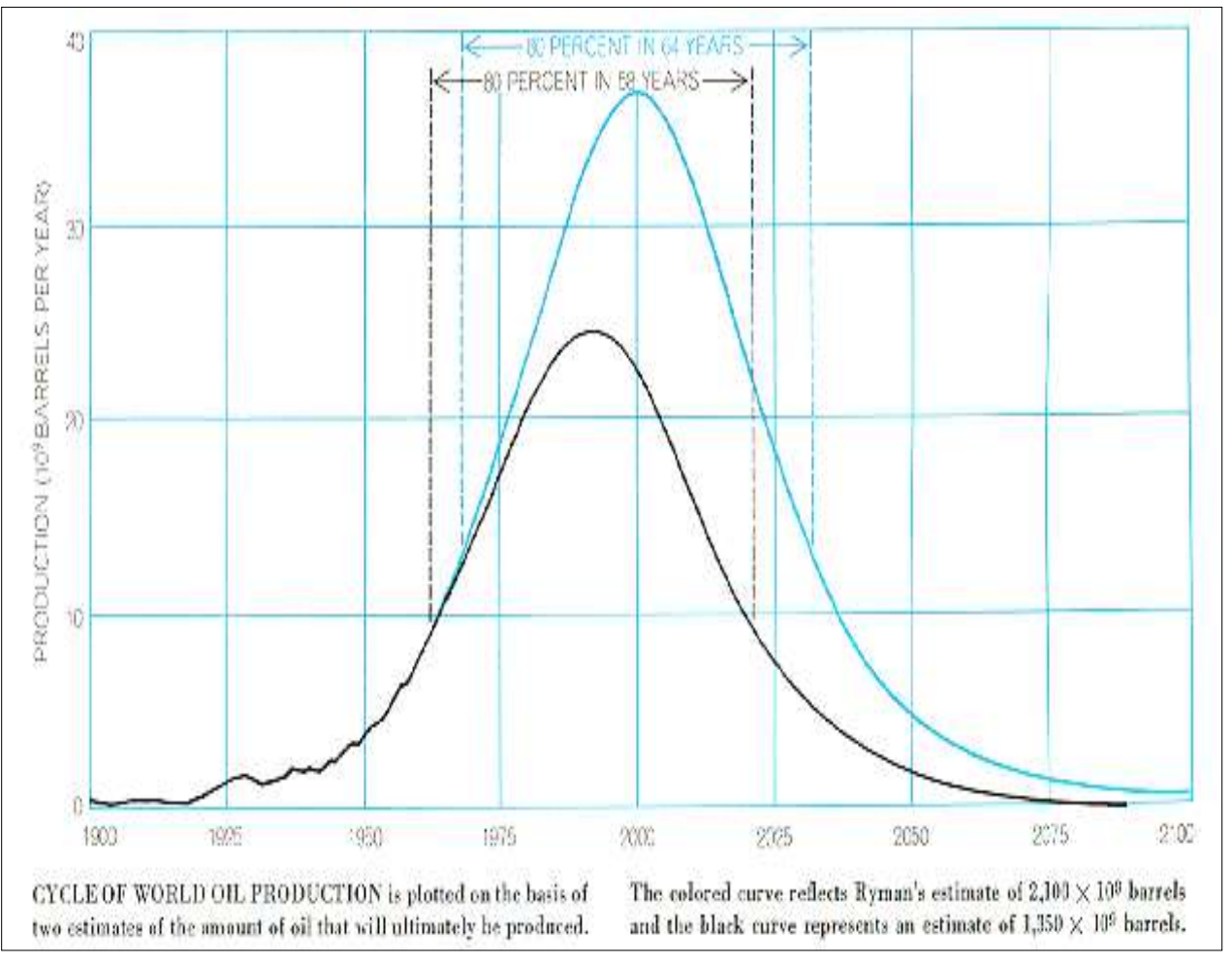

Figure (1) Huber Curve [19]

Table 1. Green gas emissions in 2005 (Canada)

[18]

\begin{tabular}{|l|l|}
\hline Transportation & $26 \%$ \\
\hline Fossil fuel industries & $19 \%$ \\
\hline Electricity and heat generation & $17 \%$ \\
\hline Agriculture & $7 \%$ \\
\hline Industrial processes (Chemical production) & $7 \%$ \\
\hline Manufacturing & $7 \%$ \\
\hline Others & $17 \%$ \\
\hline
\end{tabular}

Table 2. Wh $/ \mathrm{Kg}^{*}$ (* excluding the container) [2]

\begin{tabular}{|l|c|}
\hline Hydrogen & 39,400 \\
\hline Gasoline & 12,880 \\
\hline
\end{tabular}


Table 3 - Total energy consumption and total emissions (present vehicle)

\begin{tabular}{|c|c|c|c|c|c|c|c|c|}
\hline Method & $\begin{array}{c}\text { Fuel life } \\
\text { cycle } \\
\text { (GJ) }\end{array}$ & $\underset{\text { (ton) }}{\text { Total CO}}$ & $\begin{array}{l}\text { Vehicle life } \\
\text { cycle (GJ) }\end{array}$ & $\begin{array}{l}\text { Total } \\
\mathrm{CO}_{2} \\
\text { (ton) }\end{array}$ & $\begin{array}{l}\text { Total energy } \\
\text { in life cycle } \\
\text { (G.J) }\end{array}$ & $\begin{array}{l}\text { Total } \\
\mathrm{CO}_{2} \\
\text { (ton) }\end{array}$ & $\begin{array}{c}\text { Energy } \\
(\%)\end{array}$ & $\begin{array}{c}\text { Emissions } \\
(\%)\end{array}$ \\
\hline $\begin{array}{l}\text { Hydrogen extracted } \\
\text { from water via } \\
\text { electrolysis obtained by } \\
\text { coal and used in } \\
\text { refuelling stations }\end{array}$ & 1513 & 139.4 & 121.87 & 9.76 & 1635 & 149 & 19 & 50 \\
\hline $\begin{array}{l}\text { Hydrogen extracted } \\
\text { from NG in a power } \\
\text { plant and distributed to } \\
\text { refuelling stations }\end{array}$ & 575 & 32.49 & 121.87 & 9.76 & 697 & 42 & -49 & -57 \\
\hline $\begin{array}{l}\text { Hydrogen extracted } \\
\text { from NG in the } \\
\text { refuelling station }\end{array}$ & 607 & 34.43 & 121.87 & 9.76 & 729 & 44 & -47 & -55 \\
\hline $\begin{array}{l}\text { Hydrogen extracted } \\
\text { from water via } \\
\text { electrolysis from } \\
\text { nuclear power and } \\
\text { distributed to refuelling } \\
\text { stations }\end{array}$ & 597 & 2.97 & 121.87 & 9.76 & 719 & 13 & -48 & -87 \\
\hline $\begin{array}{l}\text { Conventional Gasoline } \\
\text { extracted from } \\
\text { petroleum and } \\
\text { distributed to refuelling } \\
\text { stations }\end{array}$ & 1255 & 89.44 & 120.12 & 9.81 & 1375 & 99 & 0 & 0 \\
\hline
\end{tabular}

Table 4. - Total energy consumption and total emissions (future vehicle)

\begin{tabular}{|c|c|c|c|c|c|c|c|c|}
\hline Method & $\begin{array}{c}\text { Fuel life } \\
\text { cycle (GJ) }\end{array}$ & $\underset{\text { (ton) }}{\text { Total } \mathrm{CO}_{2}}$ & $\begin{array}{l}\text { Vehicle } \\
\text { life } \\
\text { cycle } \\
\text { (G.J) }\end{array}$ & $\underset{\text { (ton) }}{\text { Total } \mathrm{CO}_{2}}$ & $\begin{array}{l}\text { Total } \\
\text { energy } \\
\text { in life } \\
\text { cycle } \\
\text { (GJ) }\end{array}$ & $\underset{\text { (ton) }}{\text { Total } \mathrm{CO}_{2}}$ & $\begin{array}{c}\text { Energy } \\
(\%)\end{array}$ & $\begin{array}{c}\text { Emissions } \\
(\%)\end{array}$ \\
\hline $\begin{array}{l}\text { Hydrogen extracted } \\
\text { from water via } \\
\text { electrolysis obtained } \\
\text { by coal and used in } \\
\text { refuelling stations }\end{array}$ & 1512.8 & 139.4 & 147.12 & 15.1 & 1659.9 & 154.5 & 62 & 98 \\
\hline $\begin{array}{l}\text { Hydrogen extracted } \\
\text { from NG in a power } \\
\text { plant and distributed } \\
\text { to refuelling stations }\end{array}$ & 575.11 & 32.49 & 147.12 & 15.1 & 722.23 & 47.61 & -30 & -39 \\
\hline $\begin{array}{l}\text { Hydrogen extracted } \\
\text { from NG in the } \\
\text { refuelling station }\end{array}$ & 606.94 & 34.43 & 147.12 & 15.1 & 754.06 & 49.55 & -27 & -37 \\
\hline $\begin{array}{l}\text { Hydrogen extracted } \\
\text { from water via } \\
\text { electrolysis from } \\
\text { nuclear power and } \\
\text { distributed to } \\
\text { refuelling stations }\end{array}$ & 597.29 & 2.97 & 147.12 & 15.1 & 744.41 & 18.09 & -27 & -77 \\
\hline $\begin{array}{l}\text { Conventional } \\
\text { Gasoline extracted } \\
\text { from petroleum and } \\
\text { distributed to ref. stat }\end{array}$ & 882.98 & 62.96 & 143.19 & 15.10 & 1026.1 & 78.06 & 0 & 0 \\
\hline
\end{tabular}


Table 5 - Alternative Transportation Fuels: Properties and Description

\begin{tabular}{|c|c|c|c|c|c|}
\hline Fuel & Hydrogen & Methane & Propane & Ethanol & Methanol \\
\hline Normal State & Gas & Gas & Gas & Liquid & Liquid \\
\hline Melting Temperature, $\mathrm{K}$ & 14 & 19 & 165 & 156 & 176 \\
\hline Boiling Temperature, $\mathrm{K}$ & -252 & -162 & -42 & 78 & 65 \\
\hline Heat of Evaporation/Kg & 443 & 576 & 387 & 919 & 1165 \\
\hline Liquid Handling & Cryogenic $<-252$ & Cryogenic <-162 & 1.36 Mpa @ 38 & Standard & Standard \\
\hline Toxicity & Nontoxic & Nontoxic & Nontoxic & Toxic\# & Cumulve \\
\hline
\end{tabular}

Table 6 - Alternative Transportation Fuels: Fuel characteristics (as liquid)

\begin{tabular}{|c|c|c|c|c|c|}
\hline Volumetric kg/m3 & 0.07 & 0.424 & 0.583 & 0.792 & 0.792 \\
\hline Mass Energy MJ/kg & 120 & 49.96 & 46.34 & 27.7 & 21.07 \\
\hline Vol.Energy,MU/ & 8.49 & 21.2 & 27.02 & 21.93 & 16.68 \\
\hline Ideal Air/Fuel Ratio & $34.5 / 1$ & $17.3 / 1$ & $15.7 / 1$ & $9.0 / 1$ & $6.5 / 1$ \\
\hline Research Octane NO. & N/A & 130 & 110 & 108 & 108 \\
\hline $\begin{array}{c}\text { Combustion limits Volume \% } \\
\text { Exhaust kg/GJ }\end{array}$ & $4-75$ & $5-15$ & $2.2-9.5$ & 4.3 & $7-36$ \\
\hline H20 & 75 & 45.2 & 35.3 & 43.9 & 56.4 \\
\hline $\mathrm{CO2}$ & 0 & 54.7 & 64.6 & 71.5 & 69 \\
\hline
\end{tabular}

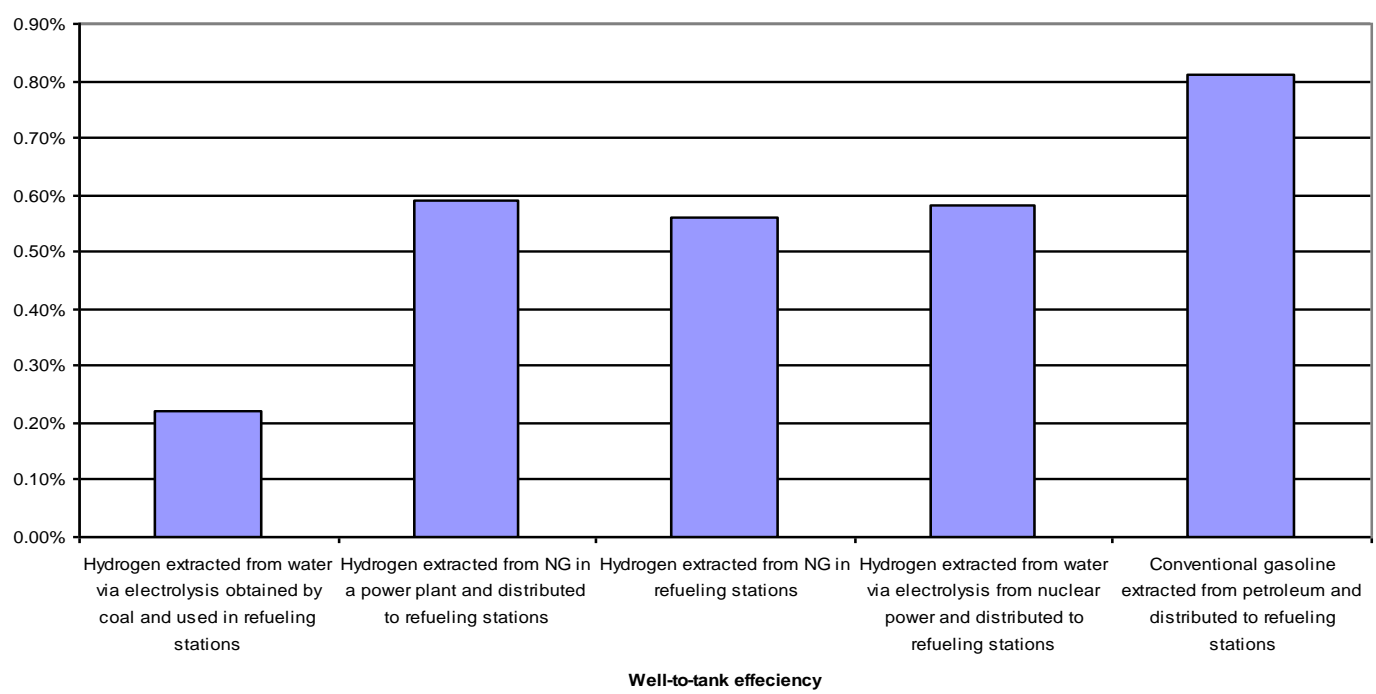

Fig 2. The well-to-tank efficiency. 


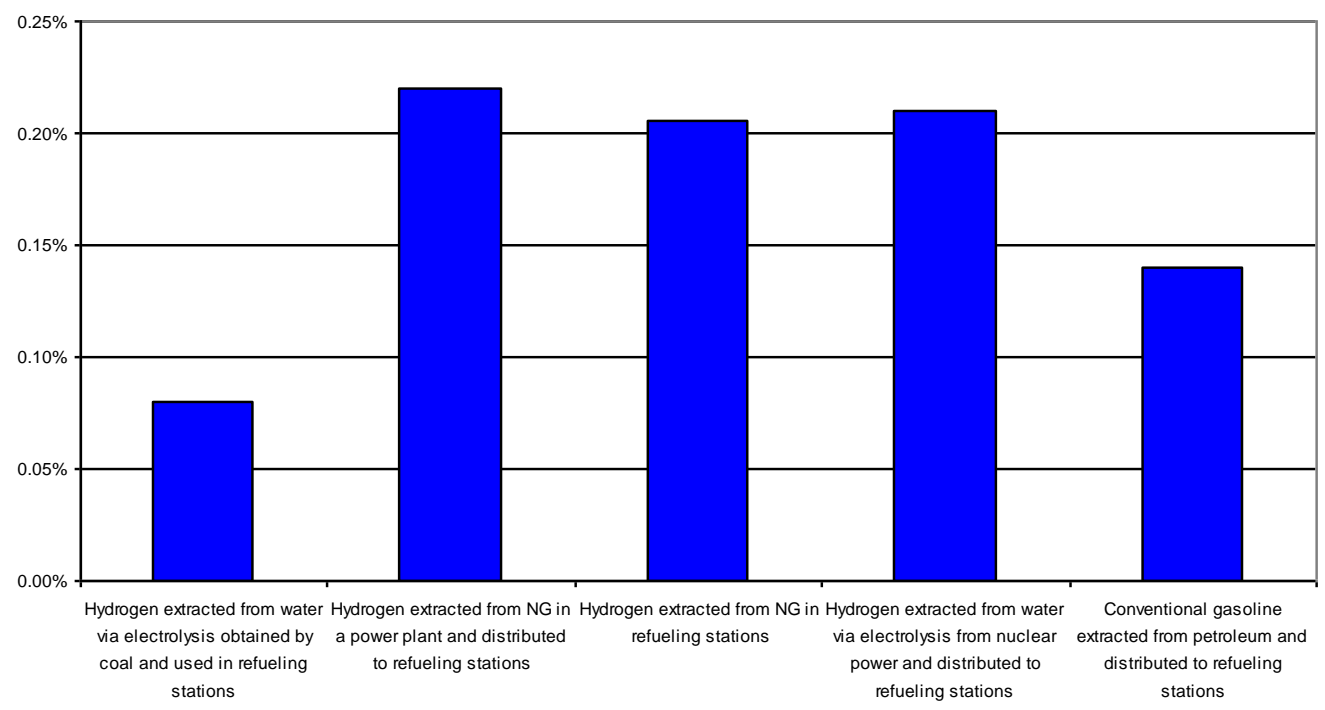

Fig 3. Well-to-wheel efficiency.

\section{References:}

1.Enzo Galloni and Mariagiovanna Minutillo, "Performance of a spark ignition engine fuelled with reformate gas produced on-board vehicle", International Journal of Hydrogen Energy, Vol. 32, Issue 13, 2532-2538,September 2007.

2.Hoolboom, G. J., Szabados, B., "Non-polluting Automobiles", IEEE transactions on Vehicular Technology, Vol.43, Issue 4, Nov.1994.

3.Hoffmann, Peter, "Tomorrow's energy: hydrogen fuel", 2002.

4.James E. Mason, "World energy analysis: $\mathrm{H}_{2}$ now or later?" Energy Policy, Vol. 35, Issue 2, pp. 13151329, February 2007.

5.Joseph Romm, "The car and fuel of the future", Energy Policy, Vol. 34, Issue 17, 2609-2614, November 2006.

6.Jamin, Yori, Raynalds, Mario, "A comparison of life- cycle greenhouse gas emissions for select fuel cell", 2000 .
7.J. J. Reilly and G. D. Sand rock, "Hydrogen storage in metal hydrides," Scientific American, 1974.

8.Jonas Hellgren, "Life cycle cost analysis of a car, a city bus and an intercity bus powertrain for year 2005 and 2020", Energy Policy, Vol. 35, Issue 1, 39-49, January 2007.

9.M.A. Weiss, J.B. Heywood, E.M. Drake, A. Schafer, F.F. Auyeung, On the road in 2020, MIT EL 00003, Eneregy Laboratory, Massachusetts Institute of Technology, Cambrige, MA 02139-4307, October 2000.

10. Stephan Ramesohl, Frank Merten, "Energy system aspects of hydrogen as an alternative fuel in transport", Energy Policy, Vol. 34, Issue 11, pp. 1251-1259, July 2006.

11.W. F. Stewart and F. J. Ederkuty, "Alternate fuels for transportation", Mech. Engineering., McMaster University, Hamilton, Canada, 22-28, June 1974.

12. Alternative fuel information for consumers, 2007. Natural Resources Canada (NRCan), 
http://oee.nrcan.gc.ca/transportation/personal/ve

13.Alternative fuels.www.fueleconomy.gov.

14.Alternative fuels and vehicles are available today.www.afvi.org/

15.Global Car Policy Research, "Alternative fuel choices,

,http://www.socsci.mcmaster.ca/polisci/gcpr/fuelc hoice.cfm.

16.Hydrogen as a transportation fuel.2002. WWW.ENERGY.CA.GOV / AFVS /.

17.U.S.addicted to oil, the globe and mail, Feb, 2006. hicle_fuels.cfm

18.Green Planet, Sunday Sun, May 2007.

19. Energy and Power, A Scientific American Book, 1971, pg 39. http://en.hubbertpeak.com

20.Energy Security Issues, http://www.globalissues.org/article ,energysecurity

21.Environmental Assessment of propane as a motor vehicles fuel. "Ph.D. report" Chandra B. Prakash, Nov, 2001

"http://www.hydrogen.energy.gov/program_record s.html.

\author{
الوقود البديل لوسائط النقل \\ طه يونس سبتي \\ قسم الهندسة الميكانيكية ـ كلية الهندسة - جامعة الكوفة
}

الخلاصةة:

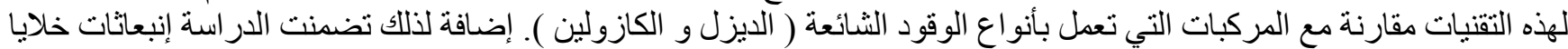

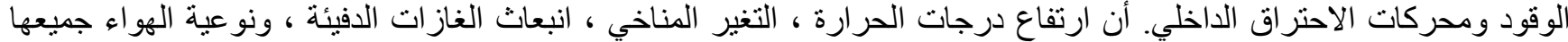

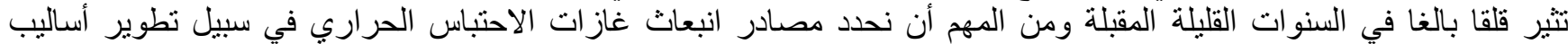

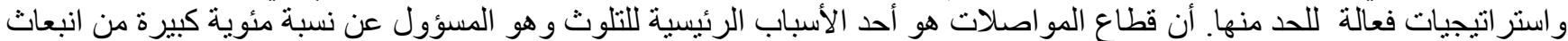

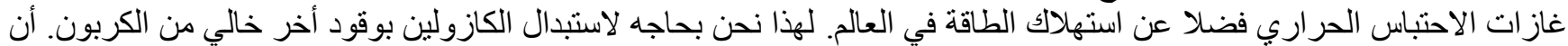

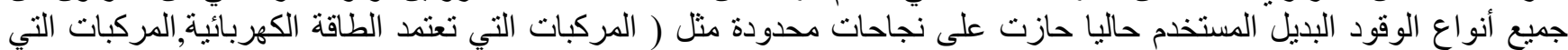
تعمل بوقود الغاز الطبيعي ,وكذللك المركبات التي تعمل بالغازات ألعضويه كلميثانول والايثانول ) والتي لاتئي استخدامها الكثير من

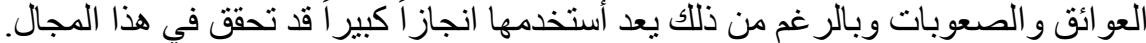

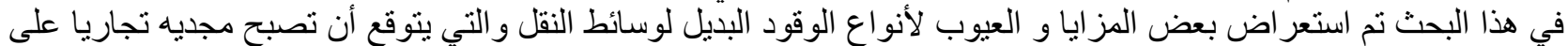

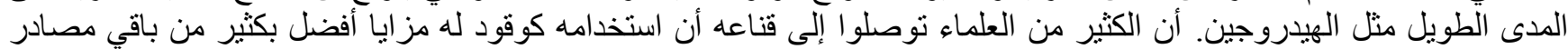

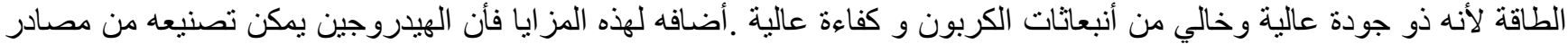
الطاقة الأولية كالغاز الطبيعي و الايثانول و الميثانول و الديزل العضوي للمساهمة في تحقيق قدر أكبر من طاقة أمنه ونظيفة للبيئة. 